\title{
KINERJA METODE ELEKTROFLOTASI PADA PENGOLAHAN AIR LIMBAH PEWARNA TEKSTIL DISPERSI
}

\author{
HARYONO *, E. EVY ERNAWATI, ATIEK ROSTIKA NOVIYANTI \\ Departemen Kimia, FMIPA, Universitas Padjadjaran \\ Jl. Raya Bandung-Sumedang Km.21 Jatinangor 45363, Sumedang, Jawa Barat \\ *email : haryono@unpad.ac.id
}

\begin{abstract}
Abstrak. Pembuangan air limbah tekstil di atas batas maksimal baku mutu ke lingkungan akan menimbulkan banyak dampak negatif terhadap ekosistem di lingkungan. Industri tekstil memanfaatkan sekitar $2 / 3$ total produk pewarna. Sekitar $10-15 \%$ dari penggunaa zat warna tersebut terbuang sebagai air limbah. Zat warna dispersi merupakan salah satu jenis pewarna sintetik yang relatif luas dimanfaat di industri tekstil. Zat warna dispersi bersifat tidak larut dalam air dan memiliki ketahanan kimia relatif tinggi. Salah satu metode yang sesuai diterapkan untuk mengolah air limbah pewarna tekstil dispersi adalah elektroflotasi. Elektroflotasi bekerja dengan prinsip dasar sebagai sel elektrolisis. Kinerja elektroflotasi dipengaruhi oleh beberapa faktor, diantaranya adalah beda potensial listrik dan lama waktu elektroflotasi. Tujuan dari penelitian ini adalah mempelajari pengaruh beda potensial listrik dan lama proses terhadap kinerja metode elektroflotasi pada pengolahan air limbah pewarna tekstil dispersi. Pada penelitian ini, kinerja elektroflotasi diukur berdasarkan kemampuan metode tersebut dalam menurunkan nilai COD (Chemical Oxygen Demand) dan tingkat warna dari air limbah tekstil yang diolah. Selain itu dihitung juga kebutuhan energi listrik spesifik dan nilai penurunan konsentrasi zat warna per satuan energi listrik. Hasil penelitian menunjukkan bahwa kondisi optimum elektroflotasi dicapai pada penggunaan beda potensial listrik sebesar $12 \mathrm{~V}$ dan waktu elektroflotasi selama 60 menit. Pada kondisi tersebut, nilai COD dan tingkat warna dari air limbah tekstil dapat diturunkan dengan efisiensi pemisahan berturut-turut sebesar 88,9\% dan 93,3\%, dengan kebutuhan energi listrik spesifik sebesar $200 \mathrm{kWh} / \mathrm{m}^{3}$. Seedangkan nilai penurunan konsentrasi zat warna per $\mathrm{kWh}$ energi listrik berdasarkan COD dan tingkat warna masing-masing adalah 16293,3 ppm/kWh dan 23333,3 Pt-Co/kWh.
\end{abstract}

Kata kunci: air limbah tekstil, elektroflotasi, efisiensi pemisahan, zat warna dispersi

\begin{abstract}
Disposal of textile wastewater above the maximum quality standard into the environment will cause many negative impacts on the ecosystem in the environment. The textile industry utilizes about $2 / 3$ of the total dye products. About $10-15 \%$ of the use of these dyes is wasted as waste water. Dispersion dyes are a type of synthetic dye that is relatively widely used in the textile industry. Disperse dyes are insoluble in water and have relatively high chemical resistance. One of the suitable methods applied to treat textile dye dispersion wastewater is electroflotation. Electroflotation works on the basic principle of an electrolytic cell. The performance of electroflotation is influenced by several factors, including the difference in electric potential and the length of time for electroflotation. The purpose of this study was to study the effect of electric potential difference and processing time on the performance of the electroflotation method in textile dye dispersion wastewater treatment. In this study, the electroflotation performance was measured based on the ability of the method to reduce the COD (Chemical Oxygen Demand) value and the color level of the treated textile wastewater. In addition, the specific electrical energy requirements and the value of the decrease in dye concentration per unit of electrical energy are also calculated. The results showed
\end{abstract}


that the optimum conditions for electroflotation were achieved by using an electric potential difference of $12 \mathrm{~V}$ and an electroflotation time of 60 minutes. Under these conditions, the COD value and color level of textile wastewater can be reduced with separation efficiency of $88.9 \%$ and $93.3 \%$, respectively, with a specific electrical energy requirement of $200 \mathrm{kWh} / \mathrm{m}^{3}$. Meanwhile, the decreasing value of dye concentration per $\mathrm{kWh}$ of electrical energy based on COD value and color level were $16293.3 \mathrm{ppm} / \mathrm{kWh}$ and 23333.3 $\mathrm{Pt}-\mathrm{Co} / \mathrm{kWh}$, respectively.

Keywords: textile wastewater, electroflotation, degree of removal, dispersion dyestuff

\section{Pendahuluan}

Industri tekstil akan selalu menjadi salah satu sektor industri strategis. Hal tersebut sebagai implikasi dari sandang sebagai komponen kebutuhan dasar manusia diproduksi dari berbagai tipe kain yang dihasilkan dari industri tekstil. Oleh karena itu kapasitas produksi tekstil akan terus meningkat seiring dengan peningkatan permintaan dari masyarakat. Namun demikian, pada proses produksi tekstil masih terdapat permasalahan mendasar terkait dengan buruknya kualitas buangan air limbah. Kondisi kualitas air limbah tekstil tersebut salah satunya merupakan kontribusi signifikan dari penggunaan zat warna pada tahap pewarnaan (dyeing) sebagai bagian dari tahap proses produksi tekstil [1].

Air limbah pewarna telah dipertimbangkan sebagai salah satu sumber polusi utama bagi lingkungan. Buangan limbah pewarna tekstil dalam konsentrasi tinggi ke badan air akan mengakibatkan penurunan kapasitas reoksigenasi dan terhalangnya sinar matahari di lingkungan perairan, sehingga mengganggu aktivitas biologi kehidupan akuatik dan juga proses fotosintesis dari tumbuhan air atau ganggang. Efek pencemaran pewarna tekstil terhadap lingkungan akuatik juga dapat disebabkan oleh efek toksik karena waktu tinggalnya yang lama di lingkungan (terakumulasi dalam sedimen terutama pada ikan atau bentuk kehidupan akuatik lainnya), pendekomposisian menjadi senyawa karsinogenik atau mutagenik, dan biodegradabilitas aerobik yang rendah $[2,3]$.

Industri tekstil terhitung merupakan sektor ekonomi yang menyerap $2 / 3$ pasar zat warna. Selama proses pewarnaan di industri tekstil, sekitar 10-15\% dari zat warna yang digunakan terbuang sebagai air limbah [4]. Oleh karena itu, peningkatan produksi tekstil akan menyebabkan peningkatan secara proporsional laju buangan air limbah pewarna. Karakteristik air limbah tekstil dilaporkan dalam berbagai jenis parameter fisika dan kimia. Dua jenis parameter dari karakteristik air limbah tekstil yang biasanya diukur adalah tingkat warna dan COD (chemical oxygen demand) [2]. Kedua parameter tersebut dapat mewakili secara langsung keberadaan zat warna di dalam air limbah tekstil. Berdasarkan laporan beberapa penelitian, air limbah tekstil memiliki karakteristik dengan tingkat warna pada rentang 240-2.500 Pt-Co dan nilai COD sebesar 150-30.000 mg/L. Khusus untuk air limbah dari tahap pewarnaan tekstil, nilai COD air limbahnya berada pada rentang $258-7561 \mathrm{mg} / \mathrm{L}$ [1]. Berdasarkan nilai COD dan tingkat warna, air limbah dari industri tekstil tersebut memiliki nilai relatif jauh di atas batas maksimum baku mutu air limbah industri tekstil menurut Peraturan Menteri Lingkungan Hidup dan Kehutanan RI No. 16 Tahun 2019, yaitu nilai COD maksimum $150 \mathrm{mg} / \mathrm{L}$ dan tingkat warna maksimum $200 \mathrm{Pt}-\mathrm{Co}$ [5].

Industri tekstil umumnya memanfaatkan zat warna sintetik. Terdapat sekitar 10 jenis zat warna sintetik tekstil, salah satunya adalah zat warna dispersi [6]. Zat warna tekstil dispersi terkelompok ke dalam zat warna tak larut dalam air dan 
diaplikasikan sebagai bubuk halus yang terdispersi di dalam bak proses pewarnaan [7]. Zat warna dispersi stabil selama pewarnaan pada suhu tinggi, berdifusi ke dalam serat tekstil dan kemudian melekat pada serat tersebut. Pewarna dispersi banyak digunakan pada pewarnaan sebagian besar serat yang diproduksi, terutama poliester dan poliamida [6].

Penanganan terhadap air limbah pewarna tekstil, khususnya untuk memperbaiki karakteristik tingkat warna dan nilai COD, dapat dilakukan dengan beberapa metode, salah satunya adalah dengan metode elektroflotasi [8]. Elektroflotasi menggunakan gelembung gas yang dihasilkan dari elektrolisis air untuk memisahkan partikel tersuspensi. Proses ini terdiri dari tangki pengolahan dengan suatu katode dan anode dimana gelembung-gelembung kecil gas hidrogen dan oksigen dihasilkan dengan penerapan arus listrik [9]. Gelembung gas tersebut terbentuk dari reaksi elektrolisis terhadap air menurut Persamaan (1) yang merupakan reaksi reduksi dan Persamaan (2) sebagai reaksi oksidasi [10].

Katode: $2 \mathrm{H}_{2} \mathrm{O}(l)+2 \mathrm{e}^{-} \rightarrow 2 \mathrm{H}_{2}(g)+2 \mathrm{OH}^{-}(a q)$

Anode: $\quad \mathrm{H}_{2} \mathrm{O}(l) \rightarrow 1 / 2 \mathrm{O}_{2}(g)+2 \mathrm{H}^{+}(a q)+2 \mathrm{e}^{-}$

Elektroflotasi memiliki beberapa keunggulan dibandingkan flotasi konvensional, yaitu: gelembung gas yang dihasilkan lebih kecil (sekitar 1-30 $\mu \mathrm{m}$ ), ukuran gelembung gas dapat dikendalikan, dan probabilitas tumbukan antara gelembung dengan partikel polutan lebih besar [11]. Pada elektroflotasi, densitas gelembung yang lebih besar meningkatkan kemungkinan tumbukan partikel-gelembung, agregasi, dan pemisahan. Selanjutnya, gelembung halus memiliki rasio permukaan terhadap volume yang lebih besar, sehingga terjadi peningkatan interaksi permukaan keseluruhan antara gelembung dan partikel. Sistem elektroflotasi biasanya tidak menyertakan bagian yang bergerak secara mekanis, sehingga pemasangan, perkuatan, dan perawatan menjadi lebih sederhana dan nyaman [12]. Kinerja elektroflotasi dalam pengolahan air limbah dipengaruhi oleh parameterparameter operasi berupa kuat arus listrik, lama waktu elektroflotasi, jenis elektode, $\mathrm{pH}$, ukuran gelembung, dan ukuran partikel polutan [13, 14].

Pengolahan air limbah dengan elektoflotasi pernah dilakukan oleh beberapa peneliti, namun dilakukan terhadap jenis limbah dan karakteristik pengoperasian yang berbeda. Penerapan elektroflotasi pada pengolahan air limbah tekstil dengan karakteristik berbeda juga akan berdampak terhadap perbedaan keoptimuman parameter operasi dari elektroflotasi. Priya et al. telah melakukan elektroflotasi pada pengolahan air limbah dari industri penyamakan kulit di Tamil Nadu, India dengan menggunakan anode dan katode berturut-turut dari material mild steel dan stainless steel. Parameter operasi berupa lama waktu elektroflotasi, densitas arus, pH air limbah, dan kadar koagulan telah dipelajari pada penelitian tersebut [13]. Belkacem et al. telah melakukan elektroflotasi pada pengolahan air limbah tekstil di Aljazair dengan aluminium sebagai elektrode [15]. Elektroflotasi juga pernah dipelajari sebagai metode pengolahan air limbah tekstil di Guangxi, China, dengan menggunakan stainless steel sebagai katode dan grafit sebagai anode [14].

Tujuan penelitian ini adalah untuk mempelajari pengaruh parameter operasi berupa lama lama waktu elektroflotasi dan beda potensial listrik terhadap pengurangan tingkat warna dan nilai COD air limbah pada pengolahan air limbah pewarna tekstil dispersi secara elektroflotasi. Pada penelitian ini digunakan stainless steel sebagai material anode dan aluminium sebagai material katode. 


\section{Metode Penelitian}

\subsection{Pengoleksian air limbah pewarna tekstil}

Pada penelitian ini, air limbah pewarna dispersi tekstil diambil dari sebuah industri tekstil di daerah Soreang, Kabupaten Bandung, Jawa Barat. Air limbah tekstil diambil dari kolam penampung akhir. Air limbah tekstil pada kolam penampung akhir tersebut merupakan hasil pencampuran air limbah dari empat unit proses produksi tekstil.

Air limbah pewarna tekstil diambil sebanyak kebutuhan untuk melakukan semua tempuhan variasi pada penelitian ini. Sampel air limbah dimasukkan ke dalam derigen dan ditutup atau disegel serta disimpan di tempat kering pada suhu untuk mencegah terjadinya perubahan karakteristik selama penyimpanan.

\subsection{Analisis kimia sampel}

Analisis kimia sampel dilakukan terhadap air limbah tekstil sebelum dan setelah elektroflotasi. Pengambilan sampel dilakukan Parameter analisis kimia sampel air limbah tersebut mencakup tingkat warna dan nilai COD. Hasil analisis tingkat warna dan COD dari kedua kelompoks sampel air limbah tekstil tersebut (sebelum dan setelah pengolahan) digunakan untuk menghitung efisiensi pemisahan zat warna tekstil dispersi dalam air limbah berdasarkan Persamaan (3).

Efisiensi Pemisahan $=\frac{\left(C_{0}-C\right)}{C_{0}} \times 100 \%$

Dengan: $\mathrm{C}_{0}$ dan $\mathrm{C}=$ konsentrasi dari parameter limbah sebelum dan setelah elektroflotasi.

Pada kondisi optimum elektroflotasi yang didasarkan pada efisiensi pemisahan zat warna tertinggi dilakukan perhitungan kebutuhan energi listrik spesifik (E). Kebutuhan energi listrik spesifik dihitung dengan Persamaan (4) berikut [16]:

$$
\mathrm{E}=\frac{\mathrm{V} \mathrm{I} \Delta \mathrm{t}}{1000 \mathrm{~V}_{\text {Limbah }}}
$$

dengan $\mathrm{V}=$ beda potensial listrik antar elektrode (volt), $\mathrm{I}=$ kuat arus listrik (ampere), $\Delta \mathrm{t}=$ lama elektroflotasi $(\mathrm{jam}$ atau $\mathrm{h}=$ hour $), \mathrm{V}_{\text {Limbah }}=$ volume limbah yang diolah $\left(\mathrm{m}^{3}\right)$, dan $1000=$ faktor konversi antara $\mathrm{W}$ (watt) dan kW (kilowatt). Selanjutnya dapat juga dihitung kemampuan elektroflotasi dalam dalam menurunkan konsentrasi zat warna pada tiap satuan kebutuhan energi listrik menurut Persamaan (5) berikut:

$$
\text { Penurunan konsentrasi zat warna per satuan energi listrik }=\frac{\left(\mathrm{C}_{0}-\mathrm{C}\right)}{\mathrm{V} \mathrm{I} \Delta \mathrm{t} / 1000} \ldots
$$

Nilai COD dan tingkat warna dari air limbah sebagai dua parameter kualitas air limbah, baik sebelum dan setelah elektroflotasi, dianalisis menurut prosedur sebagai berikut:

\subsubsection{Analisis nilai COD air limbah [8]}

Sebanyak $10 \mathrm{~mL}$ sampel air limbah tekstil dimasukkan ke dalam bejana refluks 250 mL, kemudian ditambahkan larutan $\mathrm{K}_{2} \mathrm{Cr}_{2} \mathrm{O}_{7} 0,25 \mathrm{~N}$ sebanyak $10 \mathrm{~mL}$ sebagai oksidator. Selanjutnya ditambahkan $10 \mathrm{~mL}$ larutan $\mathrm{H}_{2} \mathrm{SO}_{4} 9 \mathrm{M}$ dan $25 \mathrm{~mL}$ akuades. 
Campuran direfluks selama 2 jam. Hasil refluks kemudian didinginkan sampai suhu ruang.

Sebanyak $10 \mathrm{~mL}$ larutan hasil refluks dititrasi dengan larutan $\mathrm{Fe}\left(\mathrm{NH}_{4}\right)_{2} \mathrm{SO}_{4}$ 0,25 N menggunakan indikator feroin sampai terjadi perubahan warna dari biru kehijauan menjadi coklat kemerahan. Perlakuan yang sama diulangi terhadap blanko (akuades). Setelah dicapai titik ekivalen, nilai COD sampel dihitung dengan Persamaan (6).

$$
\mathrm{COD}=\frac{\left(\mathrm{V}_{\mathrm{b}}-\mathrm{V}_{\mathrm{s}}\right) \times \mathrm{N}_{\mathrm{FAS}} \times 8000}{\mathrm{~V}_{\text {sampel }}}
$$

Dengan: $\quad \mathrm{V}_{\mathrm{b}}=$ volume larutan $\mathrm{Fe}\left(\mathrm{NH}_{4}\right)_{2} \mathrm{SO}_{4}$ titrasi blanko, $\mathrm{V}_{\mathrm{s}}=$ volume larutan $\mathrm{Fe}\left(\mathrm{NH}_{4}\right)_{2} \mathrm{SO}_{4}$ titrasi sampel, $\mathrm{N}_{\mathrm{FAS}}=$ normalitas larutan $\mathrm{Fe}\left(\mathrm{NH}_{4}\right)_{2} \mathrm{SO}_{4}$.

\subsubsection{Analisis tingkat warna air limbah [8, 17]}

Tingkat warna sampel air limbah ditentukan dengan Nanocolor Filterfotometer (Nanocolor 25). Penentuan tingkat warna sampel didasarkan pada metode pembandingan warna antara warna sampel dengan warna standar. Warna standar disiapkan dengan mencampurkan dengan komposisi divariasikan antara larutan potasium khloroplatinat $\left(\mathrm{K}_{2} \mathrm{PtCl}_{6}\right) 1 \mathrm{mg} / \mathrm{L}$ dengan serbuk kobalt khlorida $\left(\mathrm{CoCl}_{2}\right)$. Oleh karena itu hasil pengukuran tingkat warna dari suatu sampel cairan diberi satuan Pt-Co.

\subsection{Elektroflotasi air limbah}

Air limbah pewarna tekstil dispersi sebanyak $300 \mathrm{~mL}$ dimasukkan ke dalam bak elektroflotasi batch. Pada bak elektroflotasi terangkai katode alumunium dan anode stainless steel yang dihubungkan dengan sumber energi listrik arus searah (catu daya DC) melalui kawat konduktor. Rangkaian sel elektoflotasi secara skematik ditampilkan pada Gambar 1.

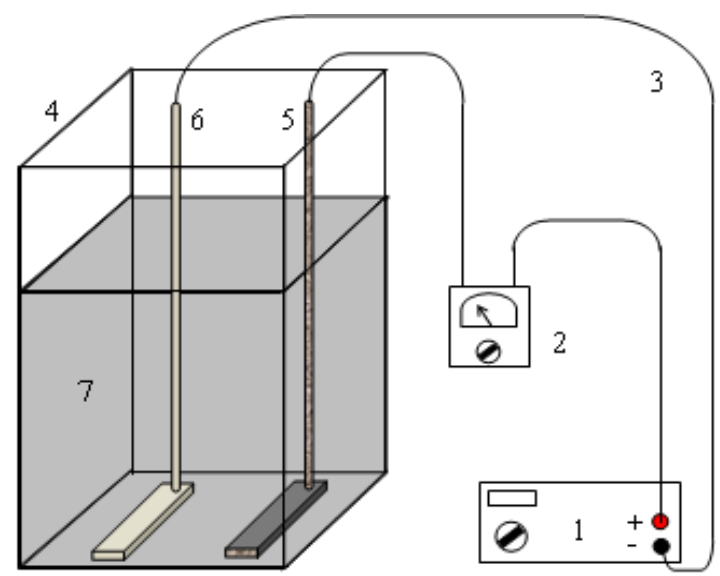

Keterangan:

1. Catu daya DC

4. Bak

6. Katode

2. Voltmeter

5. Anode

7. Air limbah

3. Kawat konduktor

Gambar 1. Skematik Diagram Sel Elektroflotasi 
Pada tahap elektroflotasi terhadap air limbah pewarna tekstil dispersi ini dipelajari pengaruh beda potensial listrik dan lama waktu elektroflotasi pada arus listrik $5 \mathrm{~A}$ terhadap efisiensi pemisahan zat warna berdasarkan nilai COD dan tingkat warna dari air limbah. Beda potensial listrik dipelajari pada variasi 6 dan 12 V. Sedangkan lama waktu elektroflotasi divariasikan selama 30, 40, 50, dan 60 menit.

\section{Hasil dan Pembahasan}

\subsection{Nilai COD dan tingkat warna air limbah pewarna tekstil dispersi sebelum pengolahan}

Air limbah tekstil sebelum diolah, secara penampilan visual cenderung terlihat berwarna hitam pekat (Gambar 2). Sedangkan hasil analisis kimia untuk parameter nilai COD, tingkat warna, dan $\mathrm{pH}$ terhadap air limbah tekstil tersebut diperoleh hasil secara berturut-turut sebesar $1100 \mathrm{mg} / \mathrm{L}, 1500 \mathrm{Pt}-\mathrm{Co}$, dan 8,8.

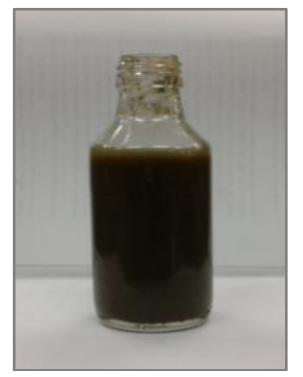

Gambar 2. Penampilan Visual Air Limbah Pewarna Tekstil Dispersi Sebelum Pengolahan

Berdasarkan parameter nilai COD dan tingkat warna, air limbah tekstil tersebut memiliki nilai COD dan tingkat warna jauh di atas batas maksimum baku mutu air limbah buangan industri tekstil menurut Peraturan Menteri Lingkungan Hidup dan Kehutanan RI No. 16 Tahun 2019, yaitu maksimum berturut-turut sebesar 150 $\mathrm{mg} / \mathrm{L}$ dan 200 Pt-Co. Parameter nilai COD didefinisikan sebagai jumlah oksigen ekuivalen yang dikonsumsi dalam reaksi oksidasi terhadap senyawa-senyawa organik oleh oksidan kuat, seperti potasium dikhromat, menjadi karbon dioksida, air, dan ion amonium [8]. Oleh karena itu nilai COD mewakili konsentrasi senyawa-senyawa organik yang terdapat dalam air atau perairan. Keberadaan senyawa-senyawa organik di dalam air atau perairan cenderung berkontribusi terhadap penurunan kualitas air dan perairan, terutama air untuk konsumsi manusia. Sedangkan parameter tingkat warna, dalam penerapannya pada polutan zat pewarna tekstil, merepresentasikan keberadaan senyawa-senyawa zat pewarna yang terdispersi secara visual di dalam air limbah.

\subsection{Pengaruh lama waktu elektroflotasi dan beda potensial beda potensial listrik terhadap nilai COD dan tingkat warna air limbah}

Hubungan antara pengaruh lama waktu elektroflotasi dan variasi beda potensial listrik pada proses elektroflotasi air limbah pewarna tekstil dispersi terhadap nilai COD dan tingkat warna air dari air limbah hasil olahan ditampilkan pada Gambar 3. 
(a)

(b)

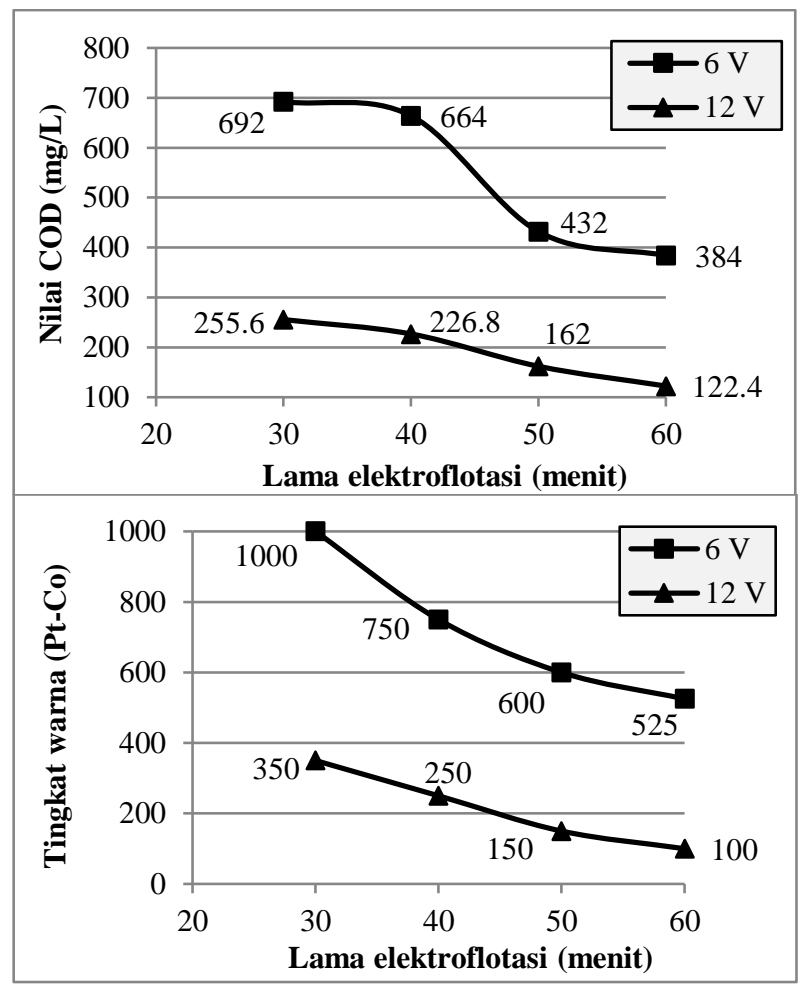

Gambar 3. Pengaruh Lama Elektroflotasi pada Beda Potensial Listrik 6 dan 12 V terhadap: (a) Nilai COD dan (b) Tingkat Warna dari Air Limbah Hasil Olahan (Nilai COD Awal = 1.100 $\mathrm{mg} / \mathrm{L}$, Tingkat Warna Awal = 1.500 Pt-Co)

Berdasarkan hasil penelitian tersebut, nampak bahwa semakin lama waktu elektroflotasi, nilai COD dan warna air hasil olahan semakin turun secara konsisten pada semua variasi beda potensial listrik yang digunakan untuk mengelektrolisis air menjadi gas $\mathrm{O}_{2}$ dan $\mathrm{H}_{2}$. Penurunan nilai $\mathrm{COD}$ dan tingkat warna tersebut menunjukkan bahwa proses elektroflotasi telah berhasil diterapkan untuk memisahkan senyawa-senyawa organik dari bahan pewarna sampai pada tingkat tertentu sesuai dengan rentang parameter operasi yang dilakukan.

Penurunan nilai COD dan tingkat warna secara konsisten seiring dengan semakin lama dan tingginya beda potensial listrik pada elektroflotasi, secara teoritis disebabkan oleh semakin banyaknya pembentukan molekul gas $\mathrm{O}_{2}$ dan $\mathrm{H}_{2}$ dari reaksi elektrolisis terhadap air sesuai reaksi reduksi-oksidasi seperti yang ditampilkan pada Persamaan (1) dan (2). Nilai kuantitatif dari lama waktu elektrolisis dan beda potensial listrik (diwakili oleh kuat arus listrik) berbanding lurus terhadap jumlah elektron yang diserahterimakan pada reaksi reduksi-oksidasi [18]. Sedangkan berdasarkan Persamaan (1) dan (2), jumlah elektron tersebut sebanding dengan jumlah spesi kimia gas $\mathrm{O}_{2}$ dan $\mathrm{H}_{2}$ sebagai agen pengapung polutan dalam air limbah yang diolah. Oleh karena itu, pada kuat arus listrik tertentu, yang nilainya sebanding dengan beda potensial listrik, maka jumlah (massa atau mol) gas $\mathrm{O}_{2}$ dan $\mathrm{H}_{2}$ yang dihasilkan akan semakin meningkat seiring dengan semakin lamanya reaksi reduksi-oksidasi pada elektroflotasi. Demikian pula jika ditinjau pada lama reaksi reduksi-oksidasi tertentu. $\mathrm{Gas}_{2}$ dan $\mathrm{H}_{2}$ yang dihasilkan akan semakin banyak dengan ditingkatkannya kuat arus listrik. Sedangkan kuat arus 
listrik, dengan hambatan diasumsikan konstan, nilainya berbanding lurus secara linier terhadap beda potensial listrik, sesuai dengan pernyataan Hukum Ohm.

Penurunan nilai COD dan tingkat warna tertinggi dari hasil elektroflotasi terhadap air limbah pewarna tekstil dispersi pada penelitian ini dicapai pada saat elektroflotasi dilakukan pada beda potensial listrik sebesar $12 \mathrm{~V}$. Elektroflotasi pada beda potensial listrik tersebut mampu menurunkan nilai COD air limbah tekstil dari 1100 menjadi 255,6 mg/L, dan tingkat warna dari 1500 menjadi 350 Pt-Co ketika elektroflotasi dilakukan selama 30 menit. Sedangkan pada beda potensial listrik 6 $\mathrm{V}$ dalam waktu elektroflotasi yang sama, nilai COD dan tingkat warna secara berturut-turut hanya turun menjadi $692 \mathrm{mg} / \mathrm{L}$ dan $1.000 \mathrm{Pt}-\mathrm{Co}$. Nilai COD semakin kecil, menunjukkan konsentrasi senyawa organik dalam air limbah sampel semakin sedikit. Sedangkan nilai Pt-Co dari suatu air sampel semakin kecil, berarti warna air sampel semakin jernih. Pada penelitian ini, penurunan nilai COD dan tingkat warna terbesar dicapai di beda potensial listrik sebesar $12 \mathrm{~V}$ pada lama elektroflotasi 60 menit, dengan nilai COD dan tingkat warna air limbah hasil olahan masing-masing sebesar 122,4 mg/L dan $100 \mathrm{Pt}-\mathrm{Co}$.

Oleh karena itu, berdasarkan syarat baku mutu air limbah industri tekstil menurut Peraturan Menteri Lingkungan Hidup dan Kehutanan RI No. 16 Tahun 2019, parameter operasi elektroflotasi terbaik dicapai pada beda potensial listrik $12 \mathrm{~V}$ dan lama waktu elektroflotasi 60 menit dengan nilai COD dari air limbah hasil olahan sebesar $122,4 \mathrm{mg} / \mathrm{L}$ dan tingkat warna $100 \mathrm{Pt}-\mathrm{Co}$. Nilai kedua parameter karakteristik air limbah tersebut telah memenuhi ketentuan baku mutu air limbah tekstil buangan. Perbandingan penampilan visual antara air limbah tekstil sebelum dan setelah elektroflotasi ditampilkan pada Gambar 4.
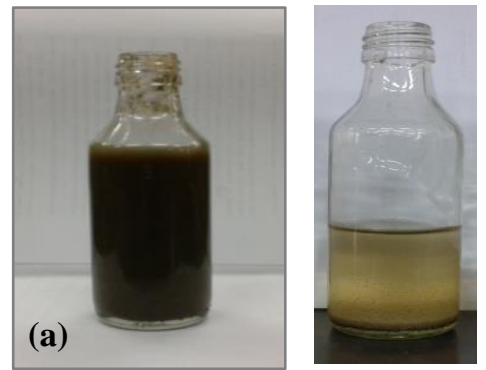

(b)

Gambar 4. Perbandingan Penampilan Visual Air Limbah Tekstil: (a) Sebelum Pengolahan,

(b) Setelah Pengolahan dengan Elektroflotasi

\subsection{Efisiensi pemisahan zat warna dispersi pada pengolahan air limbah tekstil dengan elektroflotasi}

Kinerja metode-metode pembuangan, termasuk elektroflotasi, umumnya dinyatakan sebagai efisiensi pemisahan terhadap polutan dari air yang diolah. Jenis polutan di dalam air limbah industri tekstil pada penelitian ini berupa molekulmolekul dari bahan pewarna sintetik terdispersi yang diwakili dengan parameter COD dan tingkat warna. Hubungan antara lama elektroflotasi dengan efisiensi pemisahan, didasarkan pada nilai COD dan tingkat warna, pada beda potensial listrik 12 V ditampilkan pada Gambar 5. 


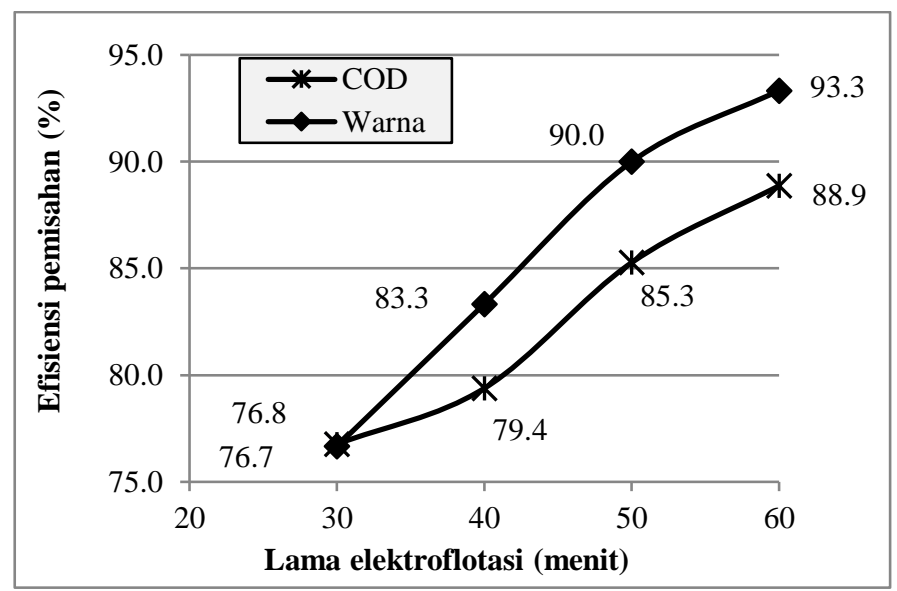

Gambar 5. Pengaruh Waktu Lama Elektroflotasi terhadap Efisiensi Pemisahan Zat Warna Tekstil Dispersi Berdasarkan Nilai COD dan Tingkat Warna dan COD pada Beda Potensial Listrik $12 \mathrm{~V}$

Gambar 5 menunjukkan bahwa dengan semakin lamanya waktu elektroflotasi, polutan zat warna tekstil terdispersi di dalam air limbah yang berhasil dipisahkan juga semakin banyak. Pada parameter operasi elektroflotasi terbaik, yaitu pada beda potensial listrik $12 \mathrm{~V}$ dan lama waktu elektroflotasi 60 jam, metode elektroflotasi mampu memisahkan zat warna dispersi dari air limbah tekstil dengan efisiensi pemisahan sebesar 88,9\% (berdasarkan nilai COD) dan 93,3\% (berdasarkan tingkat warna). Efisiensi pemisahan COD tersebut lebih besar secara signifikan dibandingan dengan efisiensi pemisahan COD yang sebesar $66 \%$ pada penerapan elektroflotasi untuk mengolah air limbah dari industri penyamakan kulit [13]. Sedangkan penerapan elektroflotasi dengan elektrode dari aluminium terhadap air limbah tekstil oleh Belkacem et al. berhasil memisahkan senyawa organik dengan efisiensi pemisahan COD sebesar 90,3\% [15]. Metode pengolahan dan air limbah sejenis, namun digunakan material katode dari stainless steal dan anode grafit, telah mampu mencapai efisiensi pemisahan COD sebesar 85\% [14].

Sesuai Gambar 5, pada elektroflotasi selama 30 menit, efisiensi pemisahan zat warna sebagai COD dan tingkat warna relatif sama. Namun mulai pada lama elektroflotasi 40 menit sampai 60 menit, terdapat perbedaan efisiensi pemisahan zat warna yang relatif signifikan antara kedua parameter tersebut. Efisiensi pemisahan polutan berdasarkan tingkat warna bernilai lebih tinggi daripada berdasarkan COD. Perbedaan tersebut diduga disebabkan oleh berbedanya jenis polutan yang diwakili masing-masing parameter mutu air tersebut. Parameter tingkat warna mewakili lebih banyak jenis polutan yang terdapat di dalam air limbah, sedangkan parameter nilai COD hanya sebatas mewakili polutan jenis senyawa organik. Sesuai hasil penelitian, polutan-polutan penyebab warna yang secara akumulasi direpresentasikan oleh parameter tingkat warna dapat dipisahkan secara signifikan ketika elektroflotasi dilakukan selama 50 dan 60 menit.

Pada elektroflotasi selama 60 menit dengan beda tegangan listrik $12 \mathrm{~V}$ memberikan efisiensi pemisahan zat warna tertinggi. Pada kondisi elektroflotasi tersebut, berdasarkan Persamaan (4), nilai kebutuhan energi listrik spesifik adalah sebesar $200 \mathrm{kWh} / \mathrm{m}^{3}$ (pada efisiensi pemisahan zat warna sebesar $88,9 \%$ berdasarkan nilai COD dan 99,3\% berdasarkan tingkat warna). Sedangkan berdasarkan Persamaan 
(5), nilai penurunan konsentrasi zat warna pada setiap $\mathrm{kWh}$ energi listrik yang diaplikasikan adalah $16293,3 \mathrm{mg} \mathrm{L}^{-1} / \mathrm{kWh}$ atau $16293,3 \mathrm{ppm} / \mathrm{kWh}$ (berdasarkan penurunan nilai COD) dan 23333,3 Pt-Co/kWh (berdasarkan penurunan tingkat warna). Sebagai perbandingan, da Mota et al. membutuhkan energi listrik spesifik sebesar $14 \mathrm{kWh} / \mathrm{m}^{3}$ untuk mencapai efisiensi pemisahan logam berat sebesar 97\% pada proses pengolahan air limbah dengan elektroflotasi [16]. Perbedaan kebutuhan energi listrik spesifik tersebut sebagai akibat perbedaan jenis polutan yang diolah. Secara umum logam berat di dalam air limbah berupa ion, sehingga lebih ringan dibandingkan dengan partikel zat warna terdispersi. Hal tersebut menyebabkan kebutuhan energi listrik spesifik pada pemisahan logam berat akan lebih rendah daripada pada pemisahan zat warna terdispersi.

\section{Kesimpulan}

Air limbah pewarna tekstil dispersi telah berhasil diolah dengan metode elektroflotasi pada parameter operasi yang dipelajari, yaitu lama waktu elektroflotasi dan beda potensial listrik. Reaksi reduksi-oksidasi pada metode elektroflotasi tersebut berlangsung pada elektrode dari material aluminium sebagai katode dan stainless steel sebagai anode.

Parameter operasi elektroflotasi terbaik pada pengolahan air limbah pewarna tekstil disperse di penelitian ini dicapai pada pemakaian beda potensial listrik $12 \mathrm{~V}$ dan waktu reaksi reduksi-oksidasi selama 60 menit. Pada parameter operasi terbaik tersebut, nilai COD air limbah tekstil dapat diturunkan dari $1100 \mathrm{mg} / \mathrm{L}$ menjadi $122,4 \mathrm{mg} / \mathrm{L}$, atau dengan efisiensi pemisahan zat warna berdasarkan nilai COD sebesar $88,9 \%$. Selain itu, karakteristik air limbah tekstil lainnya yaitu tingkat warna, berhasil diturunkan dari $1500 \mathrm{Pt}-\mathrm{Co}$ menjadi $100 \mathrm{Pt}-\mathrm{Co}$, atau dengan efisiensi pemisahan mencapai 93,3\%. Kebutuhan energi listrik spesifik sebesar 200 $\mathrm{kWh} / \mathrm{m}^{3}$, dengan penurunan konsentrasi zat warna berdasarkan nilai COD dan tingkat warna per kWh energi listrik yang diaplikasikan berturut-turut sebesar $16293,3 \mathrm{ppm} / \mathrm{kWh}$ dan 23333,3 Pt-Co/kWh.

Kualitas air limbah tekstil dari penerapan metode elektroflotasi pada parameter operasi terbaik tersebut, berdasarkan parameter nilai COD dan tingkat warna, telah memenuhi syarat baku mutu air limbah buangan industri tekstil menurut Peraturan Menteri Lingkungan Hidup dan Kehutanan No. 16 Tahun 2019, yaitu nilai COD dan tingkat warna maksimum berturut-turut sebesar $150 \mathrm{mg} / \mathrm{L}$ dan $200 \mathrm{Pt}-\mathrm{Co}$. Oleh karena itu metode elektroflotasi secara teknis sangat sesuai diterapkan sebagai metode pengolahan air limbah pewarna tekstil dispersi.

\section{Daftar Pustaka}

1. D. A. Yaseen, M. Scholz, Textile dye wastewater characteristics and constituents of synthetic effluents: a critical view, International J. of Environmental Science and Technology, Vol. 16 (2019), p. 1193-1226.

2. G. Samchetshabam, T. G. Choudhury, A. Hussam, Impact of textile dyes waste on aquatic environments and its treatment, Environment \& Ecology, Vol. 353C (2017), p. 2349-2353. 
3. B. Lellis, C. Z. Favaro-Polonio, J. A. Pamphile, J. C. Polonio, Effects of textile dyes on health and the environment and bioremediation potential of living organisms, Biotechnology Research and Innovation, Vol. 3 (2019), p. 275-290.

4. R. Kant, Textile dyeing industry an environmental hazard, Natural Science, Vol. 4 No. 1 (2012), p. 22-26.

5. Peraturan Menteri Lingkungan Hidup dan Kehutanan Republik Indonesia No. 16 Tahun 2019 tentang Perubahan Kedua Atas Peraturan Menteri Lingkungan Hidup Nomor 5 Tahun 2014 tentang Baku Mutu Air Limbah (Lampiran II tentang Baku Mutu Air Limbah Bagi Usaha Dan/Atau Kegiatan Usaha Tekstil), http://jdih.menlhk.co.id/uploads/files/P_16_2019_BAKU_MUTU_AIR_LIM BAH_menlhk_07162019080451.pdf. 14 Maret 2021.

6. M. Berradi, R. Hsissou, M. Khudhair, M. Assouag, O. Cherkaoui, A. El Bachiri, A. El Harfi, Textile finishing dyes and their impact on aquatic environs, Heliyon, Vol 5 (2019), p. 1-11.

7. J. N. Chakraborty, Fundamentals and Practices in Colouration of Textiles (2nd Edition), WPI Publishing (2014), p. 187-199.

8. C. N. Sawyer, P. L. McCarty, G. F. Parkin, Chemistry for Environtmental Engineering and Science (5th edition), McGraw-Hill Companies Inc. (2003), p. 76-85, 523-524, 625-629.

9. A. N. Andrade, R. V. Blasques, P. C. M. Villis, D. F. Silva, W. C. Gomes, Efficiency of electroflocculation in the treatment of water contaminated by organic waste, Ambiente \& Água - An Interdisciplinary Journal of Applied Science, Vol. 15 No. 2 (2020), p. 1-10.

10. X. Yanqing, J. Q. Shang, F. W. Yono, G. Gary, D. P. Coleman, M. Sioshansi, S. Sullivan, Electrokinetic flotation of process water from paint booths, Water Quality Research J. of Canada, Vol. 44 No. 2 (2009), p. 189-200.

11. S. K. A. Sarkar, Electroflotation: Its aplication to water treatment and mineral processing, Thesis in Chemical Engineering Department (2012), University of Newcastle.

12. S. R. Mohtashami, Electroflotation for treatment of paint wastewater: experiments, kinetics and hydrodynamics, $\mathrm{PhD}$ Thesis in Civil and Environmental Engineering (2018), The University of Western Ontario.

13. P. G. Priya, V. Ramamurthi, A. Prabhu, Degradation studies of tannery effluents using electroflotation technique, J. of Chemical Engineering \& Process Technology, Vol. 2 Issue 1 (2011), p. 1-4.

14. C. T. Wang, W. L. Chou, Y. M. Kuo, Removal of COD from textile wastewater by electroflotation, J. of Hazardous Materials, Vol. 164 (2013), p. 81-86.

15. M. Belkacem, M. Khodir, A. Sekki, Treatment characteristics of textile wastewater and removal of heavy metal using the electroflotation technique, Desalination, Vol. 228 (2007), p. 245-254.

16. I. O. da Mota, J. A. de Castro, R. de Goes Casqueira, A. G. de Oliviera Junior, Study of electroflotation method for treatment of wastewater from washing soil contaminated of heavy metals, J. Mater Res Technol., Vol. 4 No. 2 (2015), p. 109-113.

17. H. Effendi, Telaah Kualitas Air bagi Pengelolaan Sumber Daya dan Lingkungan Perairan (Cetakan ke-5), Penerbit Kanisius (2003), Yogjakarta.

18. R. Chang, Chemistry (10th Edition), McGraw-Hill Companies Inc. (2010) 